\title{
HUBUNGAN AGAMA DAN POLITIK: SUATU REFLEKSI TEOLOGIS-KULTURAL ${ }^{1}$ \\ Stephen Tong \\ Gereja Reformed Injili Indonesia
}

ABSTRAK: Keyakinan akan kemutlakan tidak harus mengakibatkan disharmoni antara manusia yang berbeda-beda keyakinan melainkan tetap dapat menjalankan tugas perdamaian. Antropologi Calvinisme yang meyakini adanya kebenaran, keadilan dan kesucian pada manusia mendorong pengembangan demokrasi. Anugerah umum bagi semua manusia menggerakkan sikap hati yang untuk menerima keragaman. Manusia dicipta sebagai gambar Allah merefleksikan sifat rohani untuk beribadah kepada Allah.

KATA KUNCI: Calvinisme, agama, demokrasi, anugerah umum, nasionalisme.

1 Artikel ini dikompilasi dari ceramah-ceramah Stephen Tong yang dimuat dalam buletin Veritas Dei. Judul, abstrak, pendahuluan, penutup dan catatan kaki dibuat oleh Antonius Steven Un. Termasuk di dalamnya penyesuaian bahasa untuk keperluan jurnal akademis. Un bertanggung-jawab sepenuhnya untuk hal-hal tersebut di atas. Usaha ini bukanlah tidak mendapat tantangan mengingat kapasitas Tong dalam membaca begitu luar biasa. Ia membaca begitu banyak buku dari ragam bidang. Tidak heran, Westminster Theological Seminary, yang menganugerahinya gelar doktor kehormatan menuliskan demikian, "In addition to his teaching and preaching, Dr. Tong is a true Renaissance man. He is a composer, conductor, artist, and architect, composing over 200 hymns and designing over 30 buildings." Lihat "Stephen Tong Chair", diedit 12 September 2011, diakses 16 Oktober 2014, http://www.wts.edu/stayinformed/view.html?id=1100. 
ABSTRACT: A belief on absoluteness should not cause disharmony among people with different beliefs; instead it should continue task of peace. Calvinism anthropology that believes in the existence of truth, justice and holiness in humanity encourages the development of democracy. Common grace for all mankind propels heart attitude to accept diversity. Mankind, which is created as the image of God, reflects spiritual character to worship God.

KEYWORDS: Calvinism, religion, democracy, common grace, nationalism.

\section{PENDAHULUAN}

Usaha mendasarkan politik pada teologi bukanlah sebuah usaha yang baru dan mengada-ada. Sejak dari Alkitab dan teksteks suci agama-agama, hal ini sudah dilakukan. Rasul Paulus dalam Roma 13:4 menyatakan pemerintah sebagai hamba Allah. Proyek ini kemudian diteruskan oleh teolog John Calvin (15091564) melalui bukunya Institutes of the Christian Religion ${ }^{2}$. Dalam bab IV dari masterpiece-nya, Calvin membahas mengenai posisi pemerintahan baik secara teologis maupun implikasi politisnya. Calvin membicarakan mengenai pemerintahan mulai dari eksistensinya yang sakral, bentuk pemerintahan ${ }^{3}$ hingga tugas-

2 John Calvin, Institutes of the Christian Religion, ed. John T. McNeill (Philadelphia: Westminster, 1960).

${ }^{3}$ Lihat Antonius Steven Un, "Bentuk Pemerintahan Menurut John Calvin”, Jurnal Teologi Sola Experientia, Vol. 2, No. 1 (April 2014): h. 29-49. 
tugasnya termasuk pemungutan pajak.

Usaha Calvin ini kemudian diteruskan hingga kini oleh para teolog penerusnya. Subyek pembahasan implikasi teologis terhadap dunia politik meluas hingga ke berbagai aspek ${ }^{4}$. Dalam artikel ini, usaha ini akan diteruskan dengan membahas antara lain esensi agama yang meyakini kemutlakan dengan tugas perdamaian. Lokus pembahasan kemudian dikembangkan bukan saja pada agama-agama secara umum tetapi Calvinisme secara partikular, yakni bagaimana antropologi Calvinis memberikan landasan bagi prinsip-prinsip demokrasi universal. Doktrin penting Calvinisme yakni anugerah umum kemudian direlasikan dengan isu nasionalisme dan globalisme. Artikel ini ditutup dengan suatu pendasaran teologis bagi hak dan kebebasan untuk beribadah, baik dari theology proper maupun dari sisi antropologi.

\section{AGAMA DAN MISI PERDAMAIAN 5}

Manusia selalu menginginkan dan memimpikan perdamaian. Itu sebabnya orang tua gemar menasihati anak-anak mereka untuk hidup damai. Tapi menginginkan dan memimpikan perdamaian saja tidak cukup. Untuk menciptakan perdamaian diperlukan perjuangan yang tak mengenal lelah. Agama-agama

${ }^{4}$ Sebagai contoh, lihat Antonius Steven Un, "Calvinisme dan Hak Asasi Manusia", Jurnal Teologi Reformed Injili Verbum Christi, Vol. 1, No. 1 (April 2014): h. 141-163.

5 Disarikan dari ceramah Stephen Tong, "Agama dan Misi Perdamaian" dalam Seminar Agama dan Misi Perdamaian, pada 7 Agustus 2010 di Jakarta, yang diselenggarakan oleh Reformed Center for Religion and Society. 
memiliki misi perdamaian. Umat beragama memimpikan bagaimana ide perdamaian itu mewujud dalam hidup mereka.

Ironisnya, umat beragama melakukan hal yang bertentangan dengan ide yang ada dalam agamanya itu. Bukannya perdamaian yang diperlihatkan, sebaliknya kekerasanlah yang mereka pertontonkan. Tepat seperti yang dikatakan Niccolò Machiavelli bahwa kita tidak berbicara tentang apa yang harus kita lakukan, melainkan apa yang sedang kita lakukan, karena kita sering kali tidak melakukan apa yang harus kita lakukan'

Indonesia yang terkenal dengan kerukunannya, pernah memiliki presiden dengan julukan, "the Smiling General," namun memiliki lembaran hitam kekejaman penumpasan komunis yang amat mengerikan 7 . Pada tataran teori, Indonesia memiliki ide dan

${ }^{6}$ Niccolo Machiavelli, "Petikan-Petikan dari The Prince", dalam Political Theory: Kajian Klasik dan Kontemporer, ed, Joseph Losco \& Leonard Williams, trans, Haris Munandar (Jakarta: Rajagrafindo Persada, 2005), II:23. Bandingkan ungkapan Francis Bacon, "We are much beholden to Machiavelli and others that wrote what men do, and not what they ought to do". Teks Bacon dari Warren Winiarski, "Niccolo Machiavelli", dalam History of Political Philosophy, ed. Leo Strauss \& Joseph Cropsey (Chicago: Rand McNally, 1963), h. 247.

7 Bandingkan uraian mengenai pembantaian orang-orang yang tertuduh komunis dalam M. C Ricklefs, Sejarah Indonesia Modern: 1200-2008, Trans. Tim Penerjemah Serambi (Jakarta: Serambi, 2008), 587-624. Menurut Hermawan Soelistyo, kemungkinan korban meninggal dan hilang dalam peristiwa 1965-1966 berkisar antara 78.000-2.000.000 orang. Data diambil dari Rieke Diah Pitaloka, Banalitas Kekerasan: Telaah Pemikiran Hannah Arendt tentang Kekerasan Negara (Depok: Koekoesan, 2010), h. 2. Dan menurut Benedict Anderson, antara Oktober 1965 dan Januari 1966, korban meninggal dan hilang yang teridentifikasi paling sedikit 500.000 orang. Benedict R.O'G. Anderson, Language and Power: Exploring Political Cultures in Indonesia (Ithaca and London: Cornell University Press, 1990), h. 6 . 
cita-cita tinggi tentang perdamaian. Tapi realitasnya jauh berbeda dengan apa yang ada pada tataran teori tersebut. Apa yang kita inginkan sering kali berseberangan dengan apa yang kita lakukan.

Perdamaian yang menjadi dambaan banyak orang menjadi lebih sulit dimengerti ketika diperhadapkan dengan banyaknya patung-patung pahlawan perang yang dibangun pada setiap negara. Semua orang mengajarkan, “jangan berperang, jadilah pembawa damai," tapi pada saat yang bersamaan masyarakat mengagungkan pahlawan-pahlawan perang. Jikalau manusia mencintai perdamaian, perang seharusnya dibenci. Tapi pada realitasnya perang menjadi sesuatu yang dibutuhkan untuk mendapatkan perdamaian. Ini adalah sesuatu yang sulit dipahami.

Agama yang seharusnya membawa keharmonisan, pemberi motivasi bersatu untuk perdamaian, ternyata tak mampu menghindari peperangan. Tragisnya, perang yang paling kejam dan mengerikan adalah perang atas nama agama. Salah satu faktor yang memberikan rangsangan bagi penampilan bengis agama adalah adanya konsep mutlak dalam agama. Konsep mutlak itu sendiri tidak salah, karena yang mutlak itu ada, maka lahirlah konsep mutlak, meski yang dimutlakkan manusia itu belum tentu mutlak kekal. Allah yang mutlak itu pencipta manusia, karena itu di dalam manusia yang dicipta segambar dan serupa dengan Allah memiliki konsep mutlak. Itulah yang menjadi dasar mengapa manusia mempunyai keyakinan yang tidak mau berkompromi, keyakinan itu jugalah yang menyatukan manusia dengan yang mutlak. Jadi konsep mutlak itu penting dalam beribadah, bertingkah laku, beretika, dan dalam perjuangan 
hidup. Konsep mutlak itu sendiri terbagi dua, pertama yang mutlak pada dirinya, kedua yang mutlak karena dimutlakkan, atau dengan kata lain, manusia yang memiliki konsep mutlak kemudian memutlakkan sesuatu yang tidak mutlak. Jadi sebuah kemutlakan yang diciptakan oleh konsep manusia, yang sesungguhnya bukan mutlak kekal, dan ini adalah hal yang membahayakan agama apabila konsep mutlak yang tidak kekal ini dipaksakan kepada orang lain.

Semua manusia sudah berdosa, semua manusia tidak bebas dari salah, jadi manusia tidak boleh memutlakkan dirinya, apalagi memaksakan apa yang dianggap mutlak kepada orang lain, baik dengan manipulasi maupun dengan cara-cara kekerasan. Bagi umat Kristen, Yesus adalah mutlak, Yesus satu-satunya yang mengatakan, "I am the Truth,"8 itu harus dipahami sebagai yang mutlak yang muncul dalam sejarah, bukan yang dimutlakkan manusia. Namun, Yesus juga mengajarkan untuk berdamai dengan sesama9. Artinya, kedatangan Yesus yang membawa damai justru menimbulkan pertentangan, karena berita Yesus direspon dengan penolakan dan kekerasan ${ }^{10}$. Alkitab juga

8 Yohanes 14:6, “Kata Yesus kepadanya: "Akulah jalan dan kebenaran dan hidup. Tidak ada seorang pun yang datang kepada Bapa, kalau tidak melalui Aku."

9 Matius 5:35, "Segeralah berdamai dengan lawanmu selama engkau bersama-sama dengan dia di tengah jalan, supaya lawanmu itu jangan menyerahkan engkau kepada hakim dan hakim itu menyerahkan engkau kepada pembantunya dan engkau dilemparkan ke dalam penjara."

${ }_{10}$ Matius 10:34, "Jangan kamu menyangka, bahwa Aku datang untuk membawa damai di atas bumi; Aku datang bukan untuk membawa damai, melainkan pedang." 
menyatakan bahwa Yesus tidak melakukan pemaksaan apalagi dengan cara-cara kekerasan terhadap mereka yang menolak pemberitaan-Nya, mereka yang melakukan kekerasan terhadapNya. Yesus membiarkan diri-Nya ditimpa kekerasan, dengan cara mengorbankan diri Ia mewartakan "Damai Allah."11 Karena itu, pemberitaan tentang Yesus yang mutlak mestinya jauh dari kekerasan dan manipulasi.

Barangsiapa memutlakkan diri, merasa pantas mewakili Tuhan-padahal sesungguhnya berasal dari ambisi pribadi-lalu memaksakan orang lain menerima keyakinannya, itu adalah pelanggaran terhadap hak asasi manusia. Mereka yang memutlakkan yang tidak mutlak, memutlakkan diri sebagai wakil Tuhan, kemudian menjalankan penghakiman terhadap orang lain, akan menjadi sumber kecelakaan, peperangan, dan perusak perdamaian dalam masyarakat. Umat beragama dapat menghindari bahaya dari konsep mutlak yang ada tersebut dengan cara hidup takut akan Tuhan, toleransi terhadap mereka yang beragama lain, menghargai nilai-nilai kemanusiaan, kemudian berjuang bersama-sama menegakkan perdamaian. Apabila umat beragama hidupnya takut akan Allah, agama apapun itu, maka agama-agama yang memiliki konsep Allah dapat meminimalkan kekerasan yang menodai sejarah

11 Yohanes 18:10-11, “Lalu Simon Petrus, yang membawa pedang, menghunus pedang itu, menetakkannya kepada hamba Imam Besar dan memutuskan telinga kanannya. Nama hamba itu Malkhus. Kata Yesus kepada Petrus: "Sarungkan pedangmu itu; bukankah Aku harus minum cawan yang diberikan Bapa kepada-Ku?" 
perkembangan agama-agama itu. Sebaliknya, jika agama-agama yang memiliki konsep mutlak itu tidak hidup takut akan Allah, maka agama-agama itu bisa melakukan kekerasan yang lebih mengerikan dari agama-agama yang tidak memiliki konsep Allah. Tuhan adalah Tuhan yang sabar dan toleran kepada manusia, bahkan terhadap orang yang melawan Dia sekalipun.

Umat beragama harus toleran terhadap umat beragama lain karena toleransi Tuhan amat besar. Tuhan yang penuh belas kasihan, sabar dan kebesaran hatinya dapat menampung orang yang sementara ini berperilaku tidak sesuai dengan kehendakNya. Karena itulah, masyarakat harus belajar toleran terhadap mereka yang berbeda agama. Sekalipun berseberangan dengan Jean J. Rousseau ${ }^{12}$, Voltaire menentang pembakaran buku Rousseau oleh negara. Voltaire mengatakan bahwa sebagai manusia, ia benci dengan kerajaan yang membakar buku Rousseau. Ia ingin berjuang mati-matian untuk membela hak asasi manusia yang diperjuangkan dan dimiliki oleh Rousseau. Ini adalah pikiran yang menjadi contoh bagi segala zaman.

Kita berbeda, kita harus mengakui bahwa perbedaan itu fakta. Itu sebabnya kita tidak boleh mengambil alih kekuasaan Tuhan dengan berperan sebagai Tuhan untuk kemudian

12 Mengenai silang pendapat ini, Bertrand Russel menulis, "The questions of the theology of earthquakes and of the morality of stage plays caused a bitter enmity between Voltaire and Rousseau, in which all the philosophers took sides. Voltaire treated Rousseau as a mischievous madman; Rousseau spoke of Voltaire as "that trumpet of impiety, that fine genius and that low soul". Lihat Russel, History of Western Philosophy (London \& New York: Routledge, 1996), h. 626-27. 
membunuh, memaksakan apa yang kita inginkan pada orang lain. Manusia bukan algojo Tuhan, toleransi untuk menerima perbedaan harus ada. Semua manusia itu berharga, berharkat, dan diberikan hak asasi. Ini adalah suatu penghargaan kepada sesama yang harus dimiliki semua orang. Keberagaman keyakinan adalah fakta, tetapi memaksakan keyakinan seseorang kepada orang lain merupakan pelanggaran terhadap martabat kemanusiaan. Umat beragama harus mempunyai jiwa yang lapang untuk melihat seluruh umat manusia sebagai sesama saudara meskipun memakai jubah berbeda. Manusia beragama harus berusaha menaklukkan diri, meredam nafsu, dan menghentikan ambisi liarnya, khususnya menganggap diri layak mewakili Tuhan, atau berperan sebagai Tuhan. Itu adalah musuh bersama umat manusia, yang bertentangan dengan misi perdamaian agamaagama.

\section{CALVINISME DAN DILEMA DEMOKRASI ${ }^{13}$}

Demokrasi yang marak pada abad-abad terakhir ini memiliki beberapa sumber. Pertama adalah Athena, sebuah kota sekaligus negara, yang menetapkan bahwa kekuasaan tertinggi berada di tangan rakyat, "demos" (rakyat), "kritos" (pemerintahan) ${ }^{14}$. Pandangan tersebut lalu dikembangkan oleh

${ }^{13}$ Disarikan dari ceramah Stephen Tong, "Calvinisme dan Dilema Demokrasi" dalam Seminar Calvinisme, Demokrasi Global, dan Penerapannya di Indonesia, pada 31 Agustus 2006 di Jakarta yang diselenggarakan oleh Reformed Center for Religion and Society.

${ }^{14}$ David Held mengatakan bahwa dalam konteks politik Yunani kuno, 
Calvin di Jenewa pada abad ke-16 ${ }^{15}$, hadirlah sistem politik yang sangat baru. Kemudian, pada akhir abad ke-18, cetusan demokrasi yang paling modern dikenal di Perancis, dari sana kemudian diekspor ke negara-negara lain ${ }^{16}$.

Demokrasi yang diterapkan baik di Athena maupun di Perancis sesungguhnya belum memenuhi syarat pemerintahan demokrasi. Di Athena, penduduk yang diizinkan memberikan suara tidak lebih dari 30 persen ${ }^{17}$. Perempuan, budak serta para tawanan yang dijadikan budak, dan orang kelas rendah tidak mendapat tempat dalam demokrasi Athena. Demikian juga dengan demokrasi di Perancis, dirasuki oleh semangat balas dendam, kebencian akibat penindasan pemerintahan monarki yang absolutis, mengakibatkan rakyat dengan kemarahan dan kebencian besar, menghantam, merusak, dan menghancurkan penjara Bastille ${ }^{18}$.

rakyat turut berpartisipasi dalam urusan umum; memegang kekuasaan tertinggi untuk urusan legislasi dan fungsi-fungsi yudisial. Lihat David Held, Models of Democracy, trans. Abdul Haris (Jakarta: Akbar Tanjung Institute, 2006), h. 3-24.

${ }^{15}$ Lihat uraian yang sangat teliti mengenai hal ini oleh David W. Hall, Calvin in the Public Square: Liberal Democracies, Rights and Civil Liberties (Phillipsburg: P \& R Publishing, 2009).

${ }^{16}$ Lihat bab "Calvinism in France: The Huguenot Experience" dalam buku Douglas F. Kelly, The Emergence of Liberty in the Modern World: The Influence of Calvin on Five Governments from the 16th Through 18th Centuries (Phillipsburg: P \& R Publishing, 1992), h. 37-50.

17 Lihat Held, Models of Democracy, h. 3-24.

18 Lihat kritikan terhadap Revolusi Perancis dalam Abraham Kuyper, Lectures on Calvinism (Grand Rapids: William B. Eerdmans Publishing Company, 1931), 87-90. Lihat juga Peter S. Heslam, Creating A Christian Worldview: Abraham Kuyper's Lectures on Calvinism (Grand Rapids and Carlisle: William B. Eerdmans Publishing Company and The Paternoster Press, 1998), h. 97-101. 
Pada peringatan ke-200 tahun Revolusi Perancis, Margaret Thatcher, Perdana Menteri Inggris ketika ditanya mengenai Revolusi Perancis mengatakan, penggerak Revolusi Perancis adalah bajingan-bajingan yang merebut kekuasaan dengan membuat kekacau-balauan, setelah merebut kuasa, dan terjadi kekacauan dalam masyarakat mereka pun puas ${ }^{19}$. Itulah Revolusi Perancis. Demokrasi Perancis menjunjung tinggi manusia dan kebebasan, namun tanpa ditunjang oleh ikatan moral yang sesuai dengan kebenaran. Semenjak Revolusi Perancis, semua bangsa yang tertindas mulai bergerak menumpas semua penindaspenindas demi mendapatkan kembali kedaulatan rakyat. Namun pada realitasnya, untuk menghadirkan demokrasi bukan persoalan mudah. Demokrasi bagaikan bayi dalam kandungan yang sulit untuk dilahirkan.

Pelaksanaan demokrasi menempuh jalan yang lama dan sulit, bagaikan kehamilan yang sudah amat tua dan sulit untuk tidak dilahirkan. Terkadang, kelahiran demokrasi mengakibatkan luka yang berat bagi induknya, membawa korban yang banyak di pihak rakyat. Bukan mustahil, perjuangan membangun demokrasi

19 Bandingkan kalimat Margaret Thatcher dalam wawancara radio, "I was asked about human rights and whether I thought human rights started two hundred years ago. Most certainly they did not and I gave the reasons why they go right back to Judaism, to Christianity, they go right back to Magna Carta, they go right back to our Bill of Rights, 1689 after we had our 1688, the American Statement of Independence 1776 was one of the most brilliant pieces of English literature in proclaiming the liberties of man and the government is there to serve the liberties of man". Lihat, "Radio Interview for IRN (Paris G7 Summit)", 16 Juli 1989, diakses pada 15 Oktober 2014, http://www.margaretthatcher.org/document/107734. 
menjadi suatu kecelakaan besar bagi bangsa itu. Itulah dilema demokrasi. Namun, apapun akibatnya, demokrasi harus tetap dilahirkan.

Sulitnya membangun demokrasi dialami oleh Tiongkok. Sun Yat Sen sangat tersohor dalam usaha menegakkan demokrasi di Tiongkok ${ }^{20}$. Namun itu hanya berlangsung singkat. Hanya 11 tahun setelah Tiongkok memulai demokrasi, bangkitlah seorang tirani yaitu Mao Zedong yang merebut tampuk kekuasaan dan kemudian mendirikan negara komunis. Pembunuhan demokrasi yang dilakukan Mao Zedong mengakibatkan negara Tiongkok mundur secara politik berpuluh-puluh tahun.

Sebagai negara demokrasi terbesar di dunia saat ini, India juga mengalami perjalanan yang tidak mudah. Hal ini disebabkan karena India tidak memiliki bibit demokrasi. India menjalankan demokrasi karena Mahatma Gandhi menjalankan demokrasi di India. Dan perjuangan demokrasi di India mengalami tantangan yang tidak mudah dari Hinduisme yang membagi manusia berdasarkan kasta, sehingga hak asasi manusia menjadi terbagibagi ${ }^{21}$. Perjuangan Gandhi menegakkan demokrasi di India sesungguhnya dipengaruhi kekristenan ${ }^{22}$.

${ }^{20}$ Lihat "Sun Yat-Sen", diakses pada 15 Oktober 2014, http://en.wikipedia.org/wiki/Sun_Yat-sen.

${ }^{21}$ Mahatma Gandhi mengatakan bahwa paham tak boleh bersentuhan dengan kasta yang lebih rendah sebagai "sebuah noda terbesar dalam agama Hindu". Lihat Gandhi, Semua Manusia Bersaudara, trans. Kustiniyati Mochtar (Jakarta: Yayasan Obor Indonesia, 2009), h. 9.

${ }^{22}$ Gandhi berkontak dengan kekristenan melalui buku Leo Tolstoy, The Kingdom of God is Within You (1894). Lihat "Mahatma Gandhi", diakses pada 15 
Sulitnya membangun demokrasi itu terkait dengan keharusan adanya faktor-faktor lain yang ikut andil dalam membentuk demokrasi, salah satunya adalah supremasi hukum. Faktor-faktor itu sesungguhnya ada dalam Calvinisme, dan itu terbukti dalam pembangunan demokrasi di Jenewa. Calvinisme adalah solusi untuk mengatasi dilema demokrasi. ${ }^{23}$ Calvinisme bukan hanya menggarap doktrin. Karena yang disebut doktrin adalah kepercayaan yang dipegang oleh orang berdasarkan ketaatan kepada Firman Tuhan yang mengakibatkan normalisasi relasi, secara vertikal antara manusia dengan Allah dan secara horizontal antara manusia dengan manusia.

Mengapa harus Calvinisme? Karena Calvinisme menjelaskan manusia secara tuntas. Kitab Suci menulis, manusia dicipta menurut peta dan teladan Allah. Manusia harus menjadi seperti Allah karena manusia dicipta menurut gambar-Nya. Setiap presiden yang memerintah, setiap penguasa yang berkuasa, harus menghargai serta menghormati Tuhan, dan mengerti siapa manusia yang diperintah. Teologi Reformed berhasil menjelaskan gagasan gambar dan rupa Allah dengan sangat tepat.

Oktober 2014, http://en.wikipedia.org/wiki/Mahatma_Gandhi.

23 Untuk pembahasan lebih luas mengenai aliansi yang kuat antara Calvinisme dan demokrasi, lihat A.D. Lindsay, The Essentials of Democracy (Philadelphia: University of Pennsylvania Press, 1929), James Hastings Nichols, Democracy and the Churches (Philadelphia: The Westminster Press, 1951), A.S.P. Woodhouse, ed., Puritanism and Liberty: Being the Army Debates (1647-49) from the Clarke Manuscripts with Supplementary Documents, edisi ketiga (London and Ruthland: J.M. Dent \& Sons, Ltd. and Charles E. Tuttle Co., Inc., 1992). 
Teologi Reformed, berdasarkan Efesus 4:24, menjelaskan bahwa manusia baru yang dicipta menurut peta dan teladan Allah mempunyai keadilan dan kesucian yang benar. Jadi, kesucian, keadilan, kebenaran merupakan tiga pilar penting dalam membentuk masyarakat. Bila dalam suatu masyarakat tidak terdapat kebenaran maka masyarakat tersebut adalah masyarakat barbar ${ }^{24}$. Bila dalam suatu masyarakat tidak terdapat keadilan, maka masyarakat tersebut juga akan menjadi masyarakat barbar. Bila dalam suatu masyarakat, tidak terdapat kesucian, maka masyarakat tersebut akan menjadi seperti kerumunan binatang. Ketiga pilar itu menjadikan kemungkinan manusia berkomunitas secara beres.

Selanjutnya, keadilan mengakibatkan adanya pengadilan, adanya hukum, adanya hakim, adanya jaksa, adanya Mahkamah Agung, dan sebagainya. Sifat hukum dan kesucian menjadi dasar kehidupan yang bermoral dan beretika yang berjalan di dalam segala hal yang beres dan senonoh. Dan dua hal ini didasarkan pada satu fondasi, yaitu kebenaran. Jadi, kebenaran (truth) sebagai

${ }^{24}$ Istilah "barbar" terdapat dalam Kolose 3:11, "dalam hal ini tiada lagi orang Yunani atau orang Yahudi, orang bersunat atau orang tak bersunat, orang Barbar atau orang Skit, budak atau orang merdeka, tetapi Kristus adalah semua dan di dalam segala sesuatu.". James Dunn mengatakan bahwa istilah Yunani " $\beta \alpha \rho \beta \alpha \rho \circ \varsigma^{\prime}$ " (barbaros) terutama digunakan untuk merujuk kepada "a speaker of a strange, unintelligible language". Lihat Dunn, The Epistle to the Collosians and to Philemon (Grand Rapids: William B. Eerdmans, 1996), h. 225. Kamus Besar Bahasa Indonesia menjelaskan "barbar" sebagai kata sifat yang menunjukkan ketidakberadaban. Bangsa barbar dianggap sebagai "bangsa yang belum beradab (sifatnya kasar dan kejam)". Lihat Hasan Alwi et al, ed, Kamus Besar Bahasa Indonesia (Jakarta: Pusat Bahasa Departemen Pendidikan Nasional, 2005), h. 108. 
fondasi dari righteousness dan fondasi dari kesucian. Keadilan yang sungguh-sungguh, kesucian yang sungguh-sungguh, menyebabkan masyarakat itu beres. Ketiga sifat ini membentuk manusia menjadi makhluk yang berbeda dari semua binatang.

Apabila pemerintah itu suci, adil, dan benar maka pemerintahan itu akan menjadi baik. Pemerintah yang memahami bahwa semua yang diperintahnya adalah makhluk Tuhan dan dicipta dengan pengertian kebenaran, menuntut adanya keadilan, dan pelaksanaan kesucian. Dan ini menjadi peta Allah yang menjadi dasar yang diperintah dan yang memerintah. Itu sebabnya Calvinisme akhirnya memengaruhi seluruh dunia untuk menuntut demokrasi. ${ }^{25}$

Calvinisme menuntut, melaksanakan dan memengaruhi bahwa ide yang paling tinggi untuk demokrasi bukan pada keinginan kekuasaan semata. Søren Aabye Kierkegaard mengatakan bahwa rakyat merupakan ide tertinggi dari demokrasi. Semua orang boleh saja mengatakan mengikuti amanat rakyat. Tapi siapa rakyat itu? Kierkegaard juga mengatakan bahwa mayoritas dan massa adalah anjing yang tidak ada pemiliknya.

Itu menjadi peringatan penting untuk siapa pun yang menganggap diri mewakili rakyat. "Kapan rakyat memilih kamu mewakili dia?" Hanya karena ambisi banyak orang mau

${ }^{25}$ Lihat Ralph C. Hancock, Calvin and the Foundation of Modern Politics (Ithaca and London: Cornell University Press, 1989); Samuel Huntington, The Third Wave: Democratization in the Late Twentieth Century (Norman: University of Oklahoma Press, 1991). 
memengaruhi rakyat, jadi bukan karena rakyat yang memengaruhi. Mereka yang memengaruhi lalu mengklaim diri mewakili rakyat. Itu berarti suatu perwakilan yang mewakili ketidakjujuran, ketidakbenaran, dan ketidakadilan. Itulah sebabnya demokrasi dibenci oleh Plato, karena demokrasi telah membunuh gurunya, Sokrates. Demokrasi setidaknya telah menyebabkan kematian dua orang yang paling penting di dunia ini, Sokrates dan Yesus Kristus. Itulah dilema demokrasi.

\section{NASIONALISME DAN PLURALISME GLOBAL ${ }^{26}$}

Mengapa banyak orang dari berbagai negara datang ke Bali? Apakah karena Bali memiliki ciri khas terlalu internasional? Justru karena Bali tidak ada ciri khas internasional, tetapi ciri khas Bali. Makin kita bersifat nasional, justru makin menjadi dikenal internasional ${ }^{27}$. Memiliki ciri khas mestinya bukan sesuatu yang menakutkan, dan juga tidak otomatis menjadi musuh daripada globalitas. Keduanya bisa harmonis: saling menguatkan antara yang besar dan yang kecil, yang minor dengan yang mayor, yang global dan yang lokal.

Plato, kurang lebih 2400 tahun yang lalu, pernah mengatakan bahwa, jikalau seseorang mengetahui apa yang besar dan apa yang kecil; membesarkan apa yang besar dan mengecilkan apa yang kecil; mengutamakan apa yang utama dan

${ }^{26}$ Disarikan dari ulasan Stephen Tong pada beberapa seminar.

27 Bahasa Inggrisnya: The more you are national, the more you become international. 
tidak mengutamakan apa yang tidak utama; dan merelasikan halhal yang sama-sama besar; merelasikan hal-hal yang sama-sama kecil; merelasikan antara apa yang besar dan yang kecil dan sebaliknya; maka ia akan mengikuti orang itu sampai mati. Ini adalah filsafat untuk seluruh dunia, bukan hanya untuk satu negara, juga bukan untuk satu agama, dan bukan untuk satu masyarakat.

Swiss itu satu negara, bangsa Swiss itu bangsa Swiss, tetapi bangsa Indonesia bukan hanya bangsa Jawa, melainkan bangsa suku-suku, bangsa dengan begitu banyak etnik, sehingga Indonesia adalah seperti Perserikatan Bangsa-Bangsa (PBB) yang kecil. Jika Indonesia mempunyai negarawan yang berjiwa nasionalis yang betul-betul memiliki jiwa besar, kemudian mengelola dan membuat bangsa ini penuh dengan damai, maka semua pemimpin di PBB harus belajar kepada orang di Indonesia. Berapa banyak benih nasional yang berjiwa besar di Indonesia seperti Abdurrahman Wahid (Gus Dur)? Berapa banyak orang yang masih mempunyai kemurnian jiwa nasional di Indonesia?

Sayangnya yang terjadi di Indonesia seperti apa yang dikatakan oleh Samuel Johnson, yang dijuluki singa literatur Inggris pernah mengatakan bahwa nasionalisme adalah tempat perlindungan terakhir bagi bajingan-bajingan di dalam politik ${ }^{28}$. Orang memakai nasionalisme untuk menopengi diri, tetapi hatinya tidak mencintai rakyat. Itu adalah musuh dalam selimut,

${ }^{28}$ Samuel Johnson berkata, "Patriotism is the last refuge of a scoundrel". Lihat Samuel Johnson, "Patriotism", diakses pada 15 Oktober 2014, http://www.samueljohnson.com/refuge.html. 
lebih besar daripada semua musuh internasional yang pernah ada.

Jika umat Kristen berada pada posisi mayoritas, dan memiliki pengaruh untuk menentukan kebijakan yang terkait dengan orang-orang yang beragama lain, maka orang Kristen harus memberikan ruang bagi ekspresi keagamaan umat beragama lain. Pribadi yang berjiwa besar selalu memelihara, memproteksi dan menghargai kelompok minoritas.

Jikalau satu pemerintah tidak memiliki jiwa besar, tak mungkin pemerintah menoleransi kelompok minoritas. Kelompok minoritas tidak boleh ditekan, ditindas, dihina, atau direbut kuasanya. Kelompok minoritas harus diberi pengertian, kasih, perhatian, supaya mereka dirangkul sebagai suatu bagian milik dari sebuah negara yang besar. Biarlah semua orang yang berada di negara itu mempunyai hak untuk ikut campur di dalam pembuatan sistem di dalam pemilihan dan pembatasan terhadap penguasa.

Negara besar harus berhati besar, kalau umat Kristen menjadi mayoritas, umat Kristen tidak boleh menelan, merebut hak kebebasan umat beragama lain. Kita harus menghormati umat beragama lain. Hal ini adalah sikap adil sebagai pemimpin dari suatu pemerintahan ${ }^{29}$. Umat Kristen harus hidup berkeadilan sosial.

Karena itu biarlah kita tidak perlu malu dilahirkan dalam agama apapun. Tidak ada salahnya seseorang memilih untuk memeluk suatu agama tertentu. Demikian juga tidak perlu malu

${ }^{29}$ Bahasa Inggrisnya, "the fairness of being a leader of a government". 
dilahirkan dari suku apapun. Manusia tidak bisa memilih suku. Tidak ada salahnya seseorang dilahirkan sebagai orang Tionghoa, orang Batak, orang Ambon. Tidak salah dilahirkan sebagai anggota suku apapun, tetapi jiwa kita harus melintasi suku, adat, dan keterbatasan budaya. Hal itu akan menjadikan kita berjiwa global, berjiwa internasional. Karena yang disebut nasional adalah ciri khas yang tidak bisa kita tolak.

Orang Kristen bersama-sama dengan non-Kristen wajib menjaga perdamaian dunia, kerukunan umat beragama, dan etika agar moral masyarakat tidak semakin menjadi rusak. Orang Kristen bersama dengan orang yang bukan Kristen berada dalam satu dasar bersama (common ground), yaitu sebagai ciptaan Tuhan yang sama, memiliki hati nurani, serta memiliki pengertian tentang nilai-nilai moral, meskipun standarnya berbeda. Kerjasama ini bisa memperbaiki dunia dan mengubah kebudayaan manusia.

Kehadiran pemerintah, hati nurani, sekolah, pendidikan, kebudayaan, semuanya itu membuktikan adanya kekuatan anugerah umum (common grace) Tuhan yang berada di belakang layar. ${ }^{30}$ Sepertinya manusia yang bekerja, padahal semua itu adalah pemeliharaan (providensia) Allah. Anugerah umum membuat seluruh alam semesta khususnya sistem masyarakat bisa

30 Untuk pembahasan doktrin anugerah umum, lihat Abraham Kuyper, "Common Grace: The Hinge of Kuyper's Constructive Theology" dalam James D. Bratt, ed., Abraham Kuyper: A Centennial Reader (Grand Rapids and Carlisle: William B. Eerdmans Publishing Company and The Paternoster Press, 1998), h. 165-201. 
menjadi satu penopang untuk tidak mengakibatkan kemarahan Tuhan yang terlalu cepat untuk tiba.

Anugerah umum menyatakan keagungan, kebesaran, kesabaran, dan kelimpahan anugerah Tuhan untuk menopang dunia. Melalui anugerah umum itu Allah memberkati manusia yang adalah ciptaan-Nya, memberikan kebutuhan jasmaniah secara material kepada semua manusia. Dan hal itu juga merupakan penyertaan, pemberian kecukupan dari Tuhan untuk menopang hidup seluruh manusia. Doktrin anugerah umum ini mendasari kerjasama orang Kristen yang jujur dan tulus dengan umat beragama lain tanpa harus jatuh kepada sinkretisme agama yang menafikan identitas agama-agama yang beragam.

Orang Kristen bisa bekerjasama untuk menolong orang miskin, membicarakan tentang keadilan, meskipun konsep keadilan tersebut pasti berbeda, tetapi ada konsep-konsep yang adalah anugerah Tuhan, supaya kita bisa rukun, bisa saling menghormati, di dalam hal itu kita harus mengerti bagaimana bekerja sama. Tapi, tidak ada kemungkinan untuk memimpin pada kesamaan, agama-agama itu adalah berbeda, dan memiliki konsep keselamatan yang berbeda. Kita memiliki kesamaan dengan umat agama lain karena berada di dalam bidang yang sama, namun waktu menuntaskan definisi, tetap tidak sama. Karena itu orang Kristen menerima pluralisme yang tidak menafikan keunikan agama-agama.

Bagi orang Kristen, respon yang diberikan kepada Tuhan disertai dengan pertolongan dari anugerah keselamatan (saving 
grace) sehingga anugerah umum bisa dikoreksi. ${ }^{31}$ Hal ini adalah salah satu keunikan substantif orang Kristen dibandingkan dengan agama lain.

Empedocles, filsuf Yunani 2500 tahun yang lalu menerangkan, hanya dua unsur yang mengubah seluruh dunia ${ }^{32}$. Unsur pertama mempersatukan, unsur kedua menceraiberaikan. Unsur yang mempersatukan itu unsur kasih, unsur yang menceraiberaikan itu unsur benci. Siapa musuh kita? Musuh kita bukan seperti apa yang dinilai oleh manusia. Bangsa Rusia mengatakan Amerika merupakan musuh mereka. Sebaliknya bangsa Amerika mengatakan bangsa Rusia sebagai musuh mereka. Orang Islam mengatakan bahwa orang Kristen adalah musuh sedangkan orang Kristen mengatakan bahwa Islam merupakan musuh mereka. Hal ini tidaklah benar. Musuh kita yang sesungguhnya justru adalah kebencian yang ada di dalam hati kita.

Orang Islam yang jujur lebih baik dari orang Kristen yang palsu yang bukan orang Kristen sejati. Ada pendeta palsu dan ada Muslim palsu. Pendeta yang benar dan baik dengan Muslim yang

31 Menurut Abraham Kuyper, paling sedikit ada 4 relasi common grace dan saving (special) grace: "First, the terrain of common grace that has not yet undergone any influence of special grace. Second, the terrain of the institutional church that as such arises totally and exclusively from special grace. Third, the terrain of common grace that is illuminated by the light emitted by the lamp of special grace. Fourth, the terrain of special grace that has utilized the data of common grace." Ibid., 199.

32 Teks dalam Pitirim Sorokin, "Cinta Altruistik" dalam Anatomi Cinta, A. M Krich, ed. (Depok: Komunitas Bambu, 2009), h. 370-371. 
baik menerima anugerah umum yang agak dekat dibandingkan dengan orang Kristen palsu. Kerjasama orang Kristen yang sejati dan Muslim sejati, dan juga umat beragama lain merupakan kunci bagi penyelesaian semua problematika yang menjadi pergulatan bangsa ini.

\section{KEBEBASAN MENYEMBAH TUHAN ${ }^{33}$}

Kitab suci agama Kristen menjelaskan mengenai tujuh hal yang seharusnya menjadi milik Tuhan: pujian, penghormatan, kemuliaan, bijaksana dan kelimpahan kekayaan, kuasa dan otoritas. Dan dari semua yang menjadi milik Tuhan itu, dua hal dipakai Tuhan untuk menjadi mahkota manusia, yaitu kehormatan dan kemuliaan. Kehormatan adalah dasar dari suatu sistem nilai, sedangkan kemuliaan adalah dasar dari sistem moral. Dengan kehormatan, manusia tahu bagaimana mengklasifikasikan nilai, yang kemudian menyatakan konsep aksiologi. Sedang kemuliaan adalah perihal bagaimana mengutarakan pemancaran moral dan etika untuk menjadi peta teladan Allah. Kedua hal ini menjadikan manusia bersifat unik dan lebih tinggi daripada segala binatang. Manusia adalah satu-satunya mahkluk yang mutlak mempunyai sifat agama dan sifat moral.

Tanpa agama dan moral, manusia tidak mampu melakukan klasifikasi. Manusia tidak tahu harus meninggikan siapa. Allah

33 Disarikan dari ceramah Stephen Tong, "Kebebasan Menyembah Tuhan" dalam Seminar Kebebasan Beragama atau Kerukunan Beragama? Pada 31 Maret 2012 di Jakarta, yang diselenggarakan oleh Reformed Center for Relgion and Society. 
adalah yang tertinggi, manusia bukan hanya perlu menghormati dan menghargai Allah, tetapi patut menyembah Allah. Penyembahan merupakan tingkat tertinggi ekspresi penghargaan manusia kepada Allah, karena manusia adalah milik Allah. Manusia mempunyai sifat nilai, maka dari itu penilaian yang tertinggi harus kembali kepada Allah, dan ini dinyatakan dalam penyembahan. Manusia adalah bersifat mulia, maka manusia bisa menjadi alat pemantul yang memberikan suatu refleksi, dan mengekspresikan apa yang disebut sifat ilahi. Sifat ilahi adalah menyangkut segala nilai moral. Tuhan itu adil, Tuhan itu suci, Tuhan itu kasih, Tuhan itu pemurah, Tuhan itu mempunyai kebajikan. Semua sifat ilahi itu adalah sifat dasar dan esensi dari moral, dan ini menjadi kondisi daripada etika manusia. Tanpa sifat ilahi, mustahil bicara tentang moral.

Manusia takut dan menyembah Tuhan, lalu menyatakan sifat yang ilahi, kelakuan yang menyembah Tuhan. Inilah yang dikatakan Immanuel Kant mengenai apa itu agama ${ }^{34}$. Agama adalah suatu sistem moral dan ibadah penyembahan. Penyembahan dilakukan kepada Allah. Moralitas merefleksikan sikap Allah. Jika manusia tidak berbudaya dan tidak beragama maka manusia bukan lagi manusia.

Manusia diberi hak oleh Allah untuk menyembah Tuhan, karena itu pemerintah harus melindungi hak-hak itu. Pemerintah tidak punya hak melarang, karena kekuasaan pemerintah berasal

${ }^{34}$ Lihat Lawrence Pasternack, "Kant's Philosophy of Religion" in Stanford Encyclopedia of Philosophy, diakses pada 15 Oktober 2014, http://plato.stanford.edu/entries/kant-religion/. 
dari Allah. Pemerintah berada di bawah kekuasaan Allah, pemerintah tidak eksis pada dirinya sendiri, dan setiap pemerintah harus bertanggung jawab kepada Allah. Pemerintah harus takluk kepada Allah, maka setiap pemerintahan yang tidak takluk kepada Allah patut untuk digulingkan. ${ }^{35}$

Kebebasan beragama bukan dikaruniakan oleh pemerintah, tetapi langsung diberikan oleh Tuhan. Setiap manusia adalah bermartabat, dan manusia yang bermartabat itu mempunyai kebebasan beragama, siapa pun tak berhak mencabutnya, termasuk raja atau pemerintah, karena kebebasan beragama merupakan bagian kebebasan yang hakiki. Allahlah yang berdaulat memberi manusia kebebasan, dan kebebasan itu sendiri merupakan satu bagian dari keseluruhan gambar dan rupa Allah.

Semua yang ada di dalam Allah yang menjadi bayangbayang pada manusia disebut peta dan teladan Allah. Manusia sangat berharga, karena itu manusia tidak boleh diganggu. Pemerintah-pemerintah yang mengganggu agama sama saja dengan mengarahkan diri pada hukuman Allah, atau menjerat dirinya sendiri. Tuhan lebih tinggi daripada pemerintah dan dari penguasa apapun. Namun, pemerintah yang takut kepada Tuhan dan cinta kepada rakyat, akan diingat selama-lamanya. Sebaliknya, pemerintah yang tidak takut kepada Tuhan, menindas rakyat dengan kejam, akan dihina Tuhan.

35 Calvin dan Calvinisme membuka peluang menggulingkan pemerintah melalui revolusi. Lihat Quentin Skinner, The Foundations of Modern Political Thought. Volume Two: The Age of Reformation (Cambridge: Cambridge University Press, 1978), h. 189-238, h. 302-348. 
Apabila ada orang yang mencari agama, mencari kebenaran, kemudian mereka coba mencarinya di Islam, tapi akhirnya menemukan di Kristen, apakah orang ini salah? Sebaliknya ada orang mencari Allah, coba mencari di Kristen, tapi akhirnya menemukannya di Islam, apakah orang ini salah? Manusia tak berhak melampaui Tuhan. Apabila Tuhan memberikan kebebasan kepada manusia, maka manusia tak berhak merampasnya.

Raibnya toleransi dalam diri manusia setidaknya terjadi karena dua sebab. Pertama, manusia memutlakkan dirinya. Kedua, manusia menggeser pihak yang berdaulat. Siapa yang mutlak kecuali Tuhan? Manusia tidak mutlak, tetapi kalau manusia mempunyai keyakinan yang sudah benar, silahkan saja. Itu adalah kepercayaan iman. Kalau beragama tapi tidak ada keyakinan (apa saja diterima), itu sama seperti orang yang mau menikahi siapa saja.

Agama-agama setidaknya mempunyai lima hal yang sama. Pertama, semua agama percaya bahwa manusia merupakan makhluk yang berdosa. Tanpa kepercayaan ini, agama bukanlah agama. Kedua, semua agama percaya bahwa terdapat jalan keluar bagi dosa manusia. Tanpa jalan keluar ini, manusia akan mati dalam kebinasaan. Ketiga, semua agama percaya bahwa moralitas merupakan hal yang bernilai meskipun ukurannya tidak sama dan standarnya berbeda-beda. Keempat, semua agama percaya setelah mati, manusia bukan lenyap tapi terus ada. Kelima, semua agama percaya ada kuasa supranatural di atas manusia. 
Di dalam Kisah Para Rasul 1736, Allah telah menetapkan umur dan tempat untuk setiap orang hidup di dunia, supaya mereka meraba-raba, mereka memikirkan tentang kekekalan, tentang Tuhan Allah. Karena itu semua manusia harus mempunyai toleransi, menghargai satu dengan lainnya.

Rancangan Undang-undang Kerukunan Beragama yang sedang dibahas di DPR adalah cita-cita kosong. Kalau manusia ingin hidup mau rukun maka tidak boleh mengabarkan Injil. Tetapi menginjili adalah perintah Tuhan. Jika memang ada kebebasan beragama, masakan saya tidak bisa menjalankan perintah Tuhan? Menginjili adalah perintah Tuhan, tapi penginjilan sama sekali tidak memiliki unsur memaksa, apakah diterima atau tidak diterima, itu terserah. Orang Islam juga boleh mengislamkan orang Kristen, dengan dasar kebebasan beragama. Apabila ada orang Kristen ingin menjadi pemeluk agama Islam, itu adalah haknya. Tetapi menghambat atau melarangnya adalah tidak boleh. Orang Kristen tidak perlu memusuhi agama lain. Demikian juga umat beragama lain pun tidak usah marah-marah dengan agama Kristen. Biarlah semua agama itu berkembang bersama-sama.

${ }^{36}$ Kisah Para Rasul 17:26-27: “Dari satu orang saja Ia telah menjadikan semua bangsa dan umat manusia untuk mendiami seluruh muka bumi dan Ia telah menentukan musim-musim bagi mereka dan batas-batas kediaman mereka, supaya mereka mencari Dia dan mudah-mudahan menjamah dan menemukan Dia, walaupun Ia tidak jauh dari kita masing-masing." 


\section{PENUTUP}

Jika alam politik mendapatkan legitimasi religius secara positif maka alam politik mengalami sakralisasi. Hal ini membuat kita seharusnya mensyukuri alam politik dan tidak menganggap politik dan teologi sebagai dua entitas yang beroposisi secara diametral. Sakralisasi ini bukan mempersempit ruang gerak politik, malah sebaliknya membebaskan. Meski teologi kerap memberi batasan bagi politik tetapi batasan itu bukan sesuatu yang membelenggu, malah membebaskan. Dalam metafora klasik, tembok kota bukanlah pembatas tetapi pembebas. Tembok kota membuat masyarakat dalam polis itu bebas beraktivitas dan berkreasi tanpa takut terhadap serangan binatang buas dan manusia buas dari luar tembok kota. Itulah fungsi teologi dalam mendasari aktivitas politik. 